University of Nebraska - Lincoln

DigitalCommons@University of Nebraska - Lincoln

West Central Research and Extension Center, North Platte

Agricultural Research Division of IANR

2013

\title{
Late Gestation Supplementation of Beef Cows Differing in Body Condition Score: Effects on Cow and Calf Performance
}

D. W. Bohnert

Oregon State University, dave.bohnert@oregonstate.edu

L. A. Stalker

University of Nebraska-Lincoln, stalkera@byui.edu

R. R. Mills

Oregon State University Extension Service

A. Nyman

Oregon State University

S. J. Falck

USDA-ARS

See next page for additional authors

Follow this and additional works at: https://digitalcommons.unl.edu/westcentresext

Part of the Agriculture Commons, Ecology and Evolutionary Biology Commons, and the Plant Sciences Commons

Bohnert, D. W.; Stalker, L. A.; Mills, R. R.; Nyman, A.; Falck, S. J.; and Cooke, R. F., "Late Gestation Supplementation of Beef Cows Differing in Body Condition Score: Effects on Cow and Calf Performance" (2013). West Central Research and Extension Center, North Platte. 77.

https://digitalcommons.unl.edu/westcentresext/77

This Article is brought to you for free and open access by the Agricultural Research Division of IANR at DigitalCommons@University of Nebraska - Lincoln. It has been accepted for inclusion in West Central Research and Extension Center, North Platte by an authorized administrator of DigitalCommons@University of Nebraska - Lincoln. 


\section{Authors}

D. W. Bohnert, L. A. Stalker, R. R. Mills, A. Nyman, S. J. Falck, and R. F. Cooke 


\title{
Late gestation supplementation of beef cows differing in body condition score: Effects on cow and calf performance ${ }^{1,2}$
}

\author{
D. W. Bohnert, ${ }^{3}$ L. A. Stalker, $†$ R. R. Mills,, A. Nyman, * S. J. Falck, $\S$ and R. F. Cooke* \\ *Eastern Oregon Agricultural Research Center, Oregon State University, Burns 97720; \\ $\dagger$ West Central Research and Extension Center, University of Nebraska, North Platte 69101; \\ †Oregon State University Extension Service, Pendleton 7801; and §USDA-ARS, Burns, OR 97720
}

\begin{abstract}
A 2-yr study utilizing 120 mature, crossbred (Angus $\times$ Herford) cows/year, evaluated the influence of cow BCS and dried distillers grains with solubles (DDGS) supplementation during late gestation on cow performance and productivity of subsequent offspring. Treatments were arranged as a $2 \times 2$ factorial in a randomized complete block design with $2 \mathrm{BCS}$ and with or without DDGS supplementation. Cows were nutritionally managed to enter the last trimester of gestation with a BCS of approximately 4 (LBCS) or 6 (HBCS) and were thereafter managed in a single herd (initial BCS were 4.4 and 5.7 for LBCS and HBCS treatments, respectively). During the last trimester, 12.7 $\mathrm{kg} / \mathrm{cow}$ of low quality meadow hay $(6.4 \% \mathrm{CP}$; DM basis) was provided each day. Supplemented cows were gathered and sorted into pens (12 pens; 5 cows/pen; 6 pens/BCS) every Monday, Wednesday, and Friday, and received the equivalent of $0.9 \mathrm{~kg} / \mathrm{cow}$ daily of DDGS (31\% CP; DM basis; supplement was consumed within 30 min on each supplementation day). Calf birth weight was greater for HBCS compared to LBCS $(P=0.001)$ and for supplemented compared to nonsupplemented
\end{abstract}

cows $(P=0.04)$. Cow weight at weaning was greater for HBCS compared with LBCS $(P<0.001)$; however, no differences were noted because of supplementation $(P=$ $0.16)$. Weaning weight was greater for the offspring of supplemented compared to nonsupplemented cows $(P=$ $0.02)$. There were no differences in postweaning calf performance (growing lot and feedlot) or carcass characteristics $(P>0.05)$ due to treatments. Nevertheless, HBCS cows had approximately $10 \%$ more live calves at birth and at weaning $(P \leq 0.01)$ compared to LBCS cows. Consequently, the total weaned calf weight per cow was $26 \mathrm{~kg}$ greater for HBCS compared with LBCS $(P=0.004)$. Pregnancy rate was greater $(P=0.05)$ for HBCS than LBCS cows (92\% vs. 79\%, respectively) but not affected by supplementation $(P=0.94)$. This research demonstrates the potential consequences of not maintaining cows in adequate BCS at calving. Also, though it appears that supplementation of beef cows with DDGS during late gestation has a positive effect on weaning weight, there was no apparent developmental programming effect on feedlot performance and carcass characteristics of calves.

Key words: beef cattle, body condition score, production systems, supplementation

(C) 2013 American Society of Animal Science. All rights reserved.

This article is a U.S. government work, and is not subject to copyright in the United States.
J. Anim. Sci. 2013.91:5485-5491 doi:10.2527/jas2013-6301

\section{INTRODUCTION}

Protein supplementation of late-gestation beef cows consuming low-quality forages has increased cow BW and BCS at calving (Sanson et al., 1990; Bohnert et al., 2002). Cow BCS at calving is among the most important factors affecting pregnancy rate (Richards et al., 1986), with BCS $\leq 4$ cows often becoming pregnant late in the breeding season or not at all. As a result, it is recommended that cows have a BCS of 5 to 6 prior to calving to maximize reproductive performance.

\footnotetext{
${ }^{1}$ The Eastern Oregon Agricultural Research Center, including the Burns and Union Stations, is jointly funded by the Oregon Agricultural Experiment Station and USDA-ARS. Financial support for this research was provided by the Oregon Beef Council and the Agricultural Research Foundation. Appreciation is expressed to Tony Runnels, Vern Brown Jr., Lyle Black, Lynn Carlon, and Arthur Nyman for their assistance during this study.

${ }^{2}$ USDA is an equal opportunity provider and employer.

${ }^{3}$ Corresponding author: dave.bohnert@oregonstate.edu

Received January 25, 2013.

Accepted August 5, 2013.
} 
Research has suggested that an insult to nutrition of the dam during gestation can influence the long-term health and productivity of offspring through a process that has been termed fetal, or developmental, programming (Barker, 2004; Wu et al., 2006; Reynolds et al., 2010). A growing body of evidence suggests that gestational nutrition can alter offspring body composition and growth, hormonal balance, cardiovascular development, metabolic function, neonatal health, organ development and function (Wu et al., 2006; Long et al., 2009), and gene expression (Long et al., 2010b). However, Long et al. $(2009,2010 \mathrm{~b})$ indicated that providing beef cows sufficient nutrition during late gestation can ameliorate many of the negative consequences of intrauterine growth restriction that occur in early to mid-gestation, specifically related to organ growth, animal performance, and carcass characteristics, even though some differences in organ cellular composition and function were not corrected by realimentation. Nevertheless, Stalker et al. (2006) provided supplemental protein to mature cows during the last $90 \mathrm{~d}$ of gestation and improved calf survivability, weaning performance, and economic returns. The cows used by Stalker et al. (2006) began late gestation and the supplementation period with an average $\mathrm{BCS} \geq 5$. We hypothesize cows in poor body condition $(\mathrm{BCS} \approx 4)$ will respond more favorably to supplementation than cows in good condition $(\mathrm{BCS} \approx 6)$.

The objectives of the current study were to determine the influence of cow BCS and dried distillers grains with solubles (DDGS) supplementation during the last third of gestation on cow reproductive performance, calf growth and performance through finishing in a commercial feedlot, and carcass characteristics.

\section{MATERIALS AND METHODS}

All procedures were approved by the Oregon State University Animal Care and Use Committee.

Each year for 2 yr, 120 cows were used in a randomized complete block design with a $2 \times 2$ factorial arrangement of treatments at the Eastern Oregon Agricultural Research Center (EOARC) near Burns, OR. Factors were cow BCS (Herd and Sprott, 1996) at start of the last trimester of gestation (approximately 4 or 6 ; LBCS or HBCS, respectively) and supplementation level during the last trimester of gestation $(0$ or $0.9 \mathrm{~kg}$ cow $\left.^{-1} \mathrm{~d}^{-1}\right)$. In January of each year, 120 pregnant cows were blocked by age within BCS category ( 6 blocks; 20 cows/block), and within block randomly allocated to 1 of 4 treatments ( 5 cows per treatment): LBCS with no supplementation (LBCS NS); LBCS with supplementation (LBCS S); HBCS with no supplementation (HBCS NS); HBCS with supplementation (HBCS S). The LBCS and HBCS cows were obtained each year from 120 cows selected from the EOARC herd approximately $60 \mathrm{~d}$ prior to study initiation (cow BCS was determined by 3 experienced individuals; $4.2 \pm 0.02 \mathrm{yr} 1$ and $4.4 \pm 0.29 \mathrm{yr} 2$ ). In the second year of the study, the 120 cows were selected from the EOARC cow herd with no consideration of previous treatments. Cows were stratified by age and randomly allocated to LBCS or HBCS groups, and the two groups were then nutritionally managed to obtain the target BCS (approximately BCS 4 or BCS 6) by the study start date (NRC, 2000; level 1).

At study initiation, 120 cows were placed into a 26ha flood meadow pasture that had been harvested for hay the previous summer and were offered $12.7 \mathrm{~kg} \mathrm{cow}^{-1} \mathrm{~d}^{-1}$ of low-quality (yr $1=6.6 \% \mathrm{CP}$; yr $2=6.1 \% \mathrm{CP}$; DM basis) meadow hay. Cows remained in this pasture until the day they calved. At $0700 \mathrm{~h}$ on each supplementation day the cows were gathered and all nonsupplemented cows were immediately returned to the pasture while the supplemented cows were sorted into 1 of 12 pens $(6 \times 18$ $\mathrm{m})$ based on the previous blocking structure $(5 \mathrm{cows} / \mathrm{pen}$; 6 pens/BCS category). Supplemented cows received 1.81 $\mathrm{kg} /$ cow of DDGS (yr $1=31.2 \% \mathrm{CP}$; yr $2=30.6 \% \mathrm{CP}$; $\mathrm{DM}$ basis) every Monday and Wednesday and $2.72 \mathrm{~kg} /$ cow every Friday such that the total amount of DDGS provided over the course of a week averaged $0.9 \mathrm{~kg}$ cow- 1 d-1. Cows were returned to the pasture immediately after their allocated supplement was completely consumed (approximately $30 \mathrm{~min}$ ). Samples of meadow hay and DDGS were collected weekly for determination of CP. Feed samples were ground to pass a 1-mm screen in a Wiley mill (Wiley Mill, Model 4; Arthur H. Thomas, Philadelphia, PA) and analyzed for DM (AOAC, 1996) and N (Leco CN-2000; Leco Corp., St. Joseph, MI).

On the day a cow calved, she was weighed, without restriction of feed or water, and BCS was assessed by 2 experienced technicians. Average calving date was March 18 and March 22 for yr 1 and 2, respectively. The calf was weighed, uniquely identified, castrated if male using elastrator bands (Agri-Pro Enterprises-Iowa Inc., Iowa Falls, IA), and blood was collected between 24 and $48 \mathrm{~h}$ after birth (Vacutainer; Becton Dickinson, Franklin Lakes, NJ) via jugular venipuncture and stored $\left(4^{\circ} \mathrm{C}\right)$. Serum was harvested $24 \mathrm{~h}$ after collection by centrifugation at $1,500 \times \mathrm{g}$ for $15 \mathrm{~min}$ and stored at $-20^{\circ} \mathrm{C}$ until analyzed for immunoglobulin $\mathrm{G}$ ( $\mathrm{IgG}$ ) concentration by singe radial immunodiffusion (Bovine IgG SRID kit; VMRD Inc., Pullman, WA). After being weighed, all cow/calf pairs were placed into a second 26-ha pasture and offered $13.6 \mathrm{~kg} \mathrm{cow}^{-1} \mathrm{~d}^{-1}$ of the same meadow hay as was offered precalving until all cows had calved. No supplement was provided postcalving. After all cows had calved (May 15), all cow-calf pairs were transported to the Northern Great Basin Experimental Range (NGBER) where they grazed within a 810 -ha pasture 
as a single herd for approximately $85 \mathrm{~d}$. Six bulls were introduced into the pasture on June 1 after passing a breeding soundness exam and remained with the herd for $60 \mathrm{~d}$. At the end of summer grazing (early August), calves were weaned at which time they were $150 \pm 1.3$ and $129 \pm 1.6 \mathrm{~d}$ of age for yr 1 and 2, respectively.

At weaning, cows and calves were weighed following an overnight shrink (feed and water were withheld for $16 \mathrm{~h}$ ), and BCS of cows was assessed by 3 experienced technicians. All weaned calves were transported from the NGBER to the EOARC and placed on a flood meadow pasture for $45 \mathrm{~d}$ where they grazed rake-bunched hay (Turner and DelCurto, 1991) that had been harvested in July. Weaned calves were fed $0.9 \mathrm{~kg} / \mathrm{calf}$ of DDGS every Monday and Wednesday and $1.4 \mathrm{~kg} /$ calf every Friday such that the total amount of DDGS provided over the course of a week averaged $0.45 \mathrm{~kg} \mathrm{calf}^{-1} \mathrm{~d}^{-1}$. After 45 $\mathrm{d}$, the weaned steer calves were placed in a commercial growing lot (61 $\mathrm{d}$ in yr 1; $105 \mathrm{~d}$ in yr 2$)$ and then finished in a commercial feedlot in northeast Oregon. The weaned heifer calves were retained as herd replacements; therefore, they were not used for determination of treatment effects on growing and feedlot performance or carcass characteristics. No reproductive data was collected on heifer offspring. Cows remained in a single herd at the NGBER until mid-October, with no supplemental nutrition provided, at which time they were returned to the EOARC and pregnancy status determined by rectal palpation. About 1 mo prior to calving (February 15), all cows were vaccinated against respiratory and gastrointestinal diseases using Vira Shield 5 and Clostri Shield 7 (Novartis Animal Health US, Inc., Greensboro, NC). About 2 mo after calving (May 15) all cows were treated for internal and external parasites using Dectomax injectable (Pfizer Animal Health, Madison, NJ). Additionally, all cows were vaccinated with Vira Shield $5+$ VL5 (Novartis Animal Health US, Inc.) at weaning.

At branding (mid-May), all calves were vaccinated with Clostrishield 7 and Virashield $6+$ Somnus (Novartis Animal Health US, Inc.). At weaning, calves were vaccinated with One Shot Ultra 7, Bovi-Shield Gold 5, and TSV-2 (Pfizer Animal Health). In addition, they received Dectomax injectable (Pfizer Animal Health) for treatment of internal and external parasites. Four weeks later, all calves received a booster of Bovi-Shield Gold $5+$ Somnus, Ultra Choice 7, and TSV-2 (Pfizer Animal Health).

Cow and calf performance data, excluding carcass traits, were analyzed as a randomized complete block design with supplementation pen as the experimental unit using the PROC MIXED option in SAS (SAS Inst. Inc., Cary, NC). Satterwaite approximation used to determine denominator degrees of freedom for the tests of fixed effects. The model included the effects of BCS, supplementation, and BCS $\times$ supplementation. Data were analyzed using supplementation pen $(B C S \times$ supplementation) and year as random variables. Data are reported as LS means.

The model statement used for analysis of carcass traits contained the effects of BCS, supplementation, and BCS $\times$ supplementation, whereas days on feed (DOF) was included as a covariate using PROC MIXED of SAS. Supplementation pen was used as the experimental unit. Data were analyzed using supplementation pen $(\mathrm{BCS} \times$ supplementation) and year as random variables. Also, the proportion of carcasses grading choice was analyzed using the PROC GLIMMIX procedure of SAS with Satterwaite approximation for determining denominator degrees of freedom for the test of fixed effects. As with the analysis of the aforementioned carcass traits, the model statement contained the effects of BCS, supplementation, and BCS $\times$ supplementation, with DOF included as a covariate. Data were analyzed using supplementation pen $(\mathrm{BCS} \times$ supplementation) and year as random variables.

Binomial data (cow pregnancy rate, live calves at birth and weaning, and calf sex) were analyzed as a randomized complete block design using the PROC GLIMMIX procedure of SAS with Satterwaite approximation used to determine denominator degrees of freedom for the tests of fixed effects. The model included the effects of BCS, supplementation, and BCS $\times$ supplementation. Data were analyzed using supplementation pen $(\mathrm{BCS} \times$ supplementation) and year as random variables. Data are reported as LS means.

\section{RESULTS AND DISCUSSION}

No BCS $\times$ supplementation interactions $(P>0.05)$ were noted; therefore, only main effect LS means are discussed. Also, the total number of cows removed from the study because of death, death of her calf prior to weaning, or failure to become pregnant during the breeding season was 19, 15, 4, and 6 for LBCS S, LBCS NS, HBCS S, and HBCS NS, respectively (Table 1). Consequently, $28 \%$ of LBCS cows were removed from the study compared with $8 \%$ of the HBCS cows. The number of calves that died was 9, 8, 2, and 3 for LBCS S, LBCS NS, HBCS S, and HBCS NS, respectively.

\section{Cow Performance}

At study initiation, BW of HBCS cows was $62 \mathrm{~kg}$ greater $(P<0.001)$ than LBCS cows. Also, initial BCS of treatments came close to meeting our targeted values for HBCS and LBCS cows, respectively. The HBCS cows averaged 5.7 while LBCS cows averaged $4.4(P<$ $0.001)$. At calving, the difference in BW and BCS between HBCS and LBCS cows remained $(P<0.001)$, and 
Table 1. Causes for cows being removed from the study and calf loss

\begin{tabular}{|c|c|c|c|c|}
\hline \multirow[b]{2}{*}{ Item } & \multicolumn{2}{|c|}{ LBCS } & \multicolumn{2}{|c|}{ HBCS } \\
\hline & Supp & No Supp & Supp & No Supp \\
\hline \multicolumn{5}{|l|}{$\overline{\text { Cows }}$} \\
\hline $\mathrm{N}$ & 60 & 60 & 60 & 60 \\
\hline Prepartum & $1^{\mathrm{c}}$ & 0 & 0 & 0 \\
\hline Aborted fetus & 2 & 1 & 0 & 0 \\
\hline Parturition & 0 & 0 & 0 & 0 \\
\hline Lost calf prior to turnout & $5^{\mathrm{d}}$ & $3^{\mathrm{d}}$ & 0 & 0 \\
\hline Not pregnant & 11 & 11 & 4 & 6 \\
\hline Total (all causes) & 19 & 15 & 4 & 6 \\
\hline \multicolumn{5}{|l|}{ Calves } \\
\hline Prepartum & 2 & 1 & 0 & 0 \\
\hline Parturition & $5^{\mathrm{d}}$ & $3^{\mathrm{d}}$ & 0 & 0 \\
\hline Weaning & $1^{\mathrm{e}}$ & $1^{\mathrm{e}}$ & $1^{\mathrm{e}}$ & 0 \\
\hline Growing $\operatorname{lot}^{\mathrm{a}}$ & $1^{\mathrm{f}}$ & 0 & $1^{\mathrm{g}}$ & $1^{\mathrm{h}}$ \\
\hline Finishing lot $^{\mathrm{b}}$ & 0 & $3^{\mathrm{f}, \mathrm{f}, \mathrm{g}}$ & 0 & $2^{\mathrm{f}}$ \\
\hline Total (all causes) & 9 & 8 & 2 & 3 \\
\hline \multicolumn{5}{|c|}{$\begin{array}{l}{ }^{\mathrm{a} O n l y} \text { steer calves were placed in growing lot; } \mathrm{n}=27,26,35 \text {, and } 25 \text { for } \\
\text { supplemented and non-supplemented LBCS and supplemented and non-sup- } \\
\text { plemented HBCS, respectively. }\end{array}$} \\
\hline \multicolumn{5}{|c|}{$\begin{array}{l}\text { b Only steer calves were placed in finishing lot; } \mathrm{n}=26,26,34 \text {, and } 24 \\
\text { for supplemented and non-supplemented LBCS and supplemented and non- } \\
\text { supplemented HBCS, respectively. }\end{array}$} \\
\hline \multicolumn{5}{|c|}{${ }^{\mathrm{c}}$ Cow suffocated. } \\
\hline \multicolumn{5}{|c|}{${ }^{\mathrm{d}}$ Calves born dead, no dystocia observed. } \\
\hline \multicolumn{5}{|l|}{${ }^{\mathrm{e}}$ Cause of death unknown. } \\
\hline \multicolumn{5}{|l|}{${ }^{\mathrm{f}}$ Calves died of pneumonia. } \\
\hline \multicolumn{5}{|l|}{$\mathrm{g}_{\text {Calf died of bloat. }}$} \\
\hline${ }^{\mathrm{h}}$ Crippling injury. & & & & \\
\hline
\end{tabular}

at weaning, the HBCS cows were still $29 \mathrm{~kg}$ heavier $(P<$ $0.001)$ and had a 0.5 greater $(P<0.001)$ BCS than LBCS cows. These data agree with those reported by Stalker et al. (2007) who showed cows with greater BW and BCS at the beginning of the last trimester of gestation also had greater BW and BCS at calving and at weaning.

As with BCS treatments, BW and BCS of supplemented and nonsupplemented cows were similar at study initiation ( $P \geq 0.41$; Table 2$)$. However, supplemented cows weighed $34 \mathrm{~kg}$ more $(P=0.002)$ and had 0.2 greater $(P=0.005)$ BCS than nonsupplemented cows at calving. This agrees with other work in which DDGS was supplemented to mature beef cows consuming lowquality forage in late gestation (Winterholler et al., 2012). However, no difference in BW of supplemented and nonsupplemented cows was noted at weaning $(P=0.16)$ but there was a tendency $(P=0.08)$ for supplemented cows to have a greater BCS than nonsupplemented. Our data agrees with numerous reports documenting the effect of protein supplementation of cows consuming poor quality forage during late gestation on BW and BCS (Randel, 1990; Bohnert et al., 2002; Stalker et al., 2007).

Percentage of cows that became pregnant during the study was not affected by supplementation treatment $(\mathrm{P}=$ $0.94)$; however, there was a difference $(\mathrm{P}=0.05)$ between HBCS and LBCS treatments. The average pregnancy rate for $\mathrm{LBCS}$ cows was $79 \%$ compared to $92 \%$ for the HBCS cows (Table 2). Body condition score at calving has been shown to influence pregnancy rates and interval from calving to pregnancy (DeRouen et al., 1994). Mature cows calving with a BCS 5 or greater become pregnant in fewer days than do cows calving with a BCS 4 or less (Richards et al., 1986). Our breeding season was 60 d, so it is possible that a longer breeding season may have resulted in a greater overall pregnancy rate for the LBCS cows; however, if length of the breeding season were limiting pregnancy rate, lengthening the breeding season would increase the calving interval and decrease the average age and $\mathrm{BW}$ of calves at a common weaning date.

\section{Calf Performance}

No effects on calf birth date were observed for LBCS or HBCS cows $(P=0.59)$ or for supplementation treatments $(P=0.48$; Table 3$)$. Also, no difference in the proportion of live calves at birth and weaning were observed due to supplementation $(P>0.27)$; however, the percentage of live calves at birth for the HBCS cows was $100 \%$ compared with $90 \%$ for the LBCS cows $(P=0.003)$. Also, the percentage of live calves at weaning was greater for HBCS, averaging $99 \%$ and $88 \%$ for HBCS and LBCS

Table 2. Body weight, BCS and reproductive performance of cows managed to enter the last trimester of gestation in low BCS (LBCS; approximately 4) or high BCS (HBCS; approximately 6) and offered 0.0 (No) or $0.9 \mathrm{~kg} / \mathrm{d}$ (Yes) of dried distillers grains plus solubles during the last trimester of gestation ${ }^{1}$

\begin{tabular}{|c|c|c|c|c|c|c|c|c|}
\hline \multirow[b]{2}{*}{ Item } & \multicolumn{4}{|c|}{$\mathrm{BCS}$} & \multicolumn{4}{|c|}{ Supplementation } \\
\hline & LBCS & HBCS & SEM & $P$-value & No & Yes & SEM & $P$-value \\
\hline Initial BW, kg & 503 & 565 & 14.7 & $<0.001$ & 535 & 533 & 14.7 & 0.81 \\
\hline Calving BW, kg & 513 & 554 & 13.2 & $<0.001$ & 516 & 550 & 13.2 & 0.002 \\
\hline Weaning BW, kg & 518 & 547 & 27.6 & $<0.001$ & 528 & 537 & 27.6 & 0.16 \\
\hline Initial BCS & 4.4 & 5.7 & 0.13 & $<0.001$ & 5.1 & 5.0 & 0.13 & 0.41 \\
\hline Calving BCS & 4.4 & 5.3 & 0.06 & $<0.001$ & 4.8 & 5.0 & 0.06 & 0.005 \\
\hline Weaning BCS & 4.7 & 5.2 & 0.15 & $<0.001$ & 4.9 & 5.0 & 0.15 & 0.08 \\
\hline Pregnancy rate, \% & 79.3 & 91.6 & 4.14 & 0.05 & 85.2 & 85.6 & 4.14 & 0.94 \\
\hline
\end{tabular}

${ }^{1}$ Initial BCS and BW was determined at study initiation, approximately $80 \mathrm{~d}$ prior to calving. 
Table 3. Performance of calves born to cows that entered the last trimester of gestation in low BCS (LBCS; approximately 4) or high BCS (HBCS; approximately 6) and offered 0.0 (No) or $0.9 \mathrm{~kg} / \mathrm{d}$ (Yes) of dried distillers grains with solubles during the last trimester of gestation

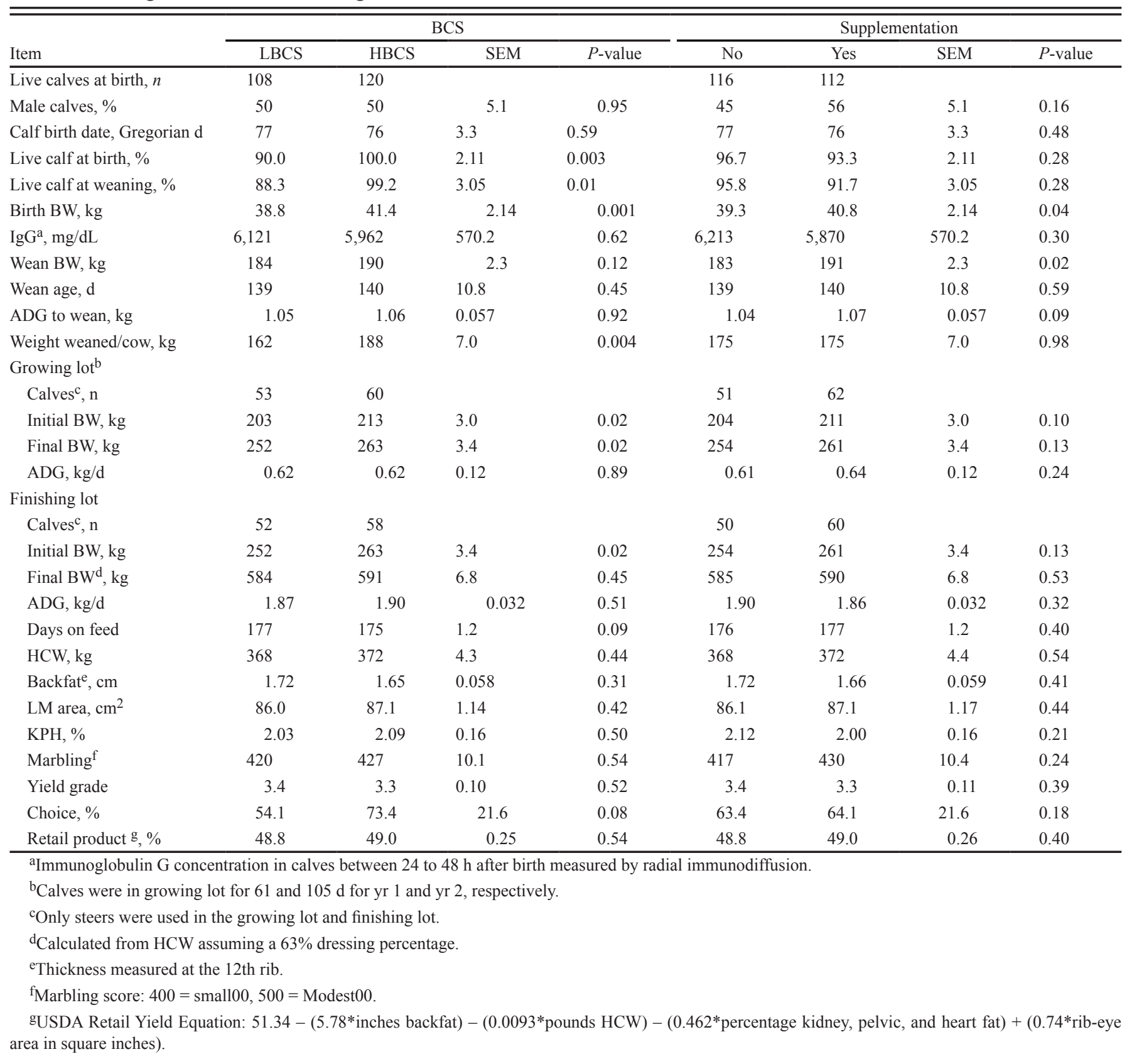

cows, respectively $(P=0.01)$. A reduction in live calves at weaning caused by nutrient restriction (Corah et al., 1975) or a lack of supplementation (Stalker et al., 2006) during the last trimester of gestation has been reported. However, like Stalker et al. (2007) we did not observe an effect of supplementation on live calves at weaning. Nevertheless, we did observe an effect of cow BCS during the last trimester of gestation on percentage of live calves at weaning which is in contrast to the results reported by Stalker et al. (2007). The difference between the two studies could be because the BCS of cows in our study was lower. The LBCS cows in our study entered the last trimester of gestation with a BCS of 4.4 whereas the November weaned cows in Stalker et al. (2007) entered the last trimester of gestation with a BCS of 5.0.

Calf birth weight was $2.6 \mathrm{~kg}$ greater $(P=0.001)$ for HBCS cows compared to LBCS cows (Table 3 ) and 1.5 $\mathrm{kg}$ greater $(P=0.05)$ for supplemented compared to nonsupplemented cows; no incidents of dystocia were noted during the study. The effect of supplementation during gestation on calf birth weight has been inconclusive, with some studies showing an increase in birth weight (Clanton and Zimmerman, 1970; Larson et al., 2009; Winterholler et al., 2012) but most showing no influence of supplementation on calf birth weight (Bohnert et al., 2002; Currier et al., 2004; Stalker et al., 2006). The reason for the ap- 
parent inconsistencies is not readily apparent; however, it is possible that differences in the type and amount of supplements used in the studies could have influenced fetal growth. In support of our data, Winterholler et al. (2012) supplemented late-gestation cows with DDGS and noted an increase in calf birth weight. These authors implied that added energy from DDGS supplementation may have been partitioned to help support fetal growth.

The increased birth weight of calves from HBCS compared with LBCS cows is most likely due to the improved energy status and body condition of the HBCS cows. Spitzer et al. (1995) and Winterholler et al. (2012) reported that increasing cow BCS during late gestation increased calf birth weight. In addition, lower calf birth weights have been documented from cows with lower body weight and/or decreased precalving nutrient intake (Bellows et al., 1971; Bellows and Short, 1978; Corah et al., 1975). Therefore, the improved energy status of the HBCS compared with the LBCS cows prior to study initiation may have ameliorated the potential negative effects on calf birth weight resulting from the lower energy status of the LBCS cows. There was no effect of treatment on calf serum IgG level at birth $(P \geq 0.30)$, and all IgG levels were sufficient to indicate successful transfer of passive immunity to the calf (Tyler et al., 1996).

Calf BW at weaning was not influenced by cow BCS $(P=0.12)$ but was increased for calves from supplemented compared to nonsupplemented cows $(P=0.02$; Table 3). This data agrees with previous work indicating that supplementation of cows precalving increases weaning performance of steer (Larson et al., 2009; Stalker et al., 2006, 2007) and heifer (Funston et al., 2010) offspring. Also, improved weaning performance of calves has been reported from cows receiving a greater plane of nutrition than those experiencing nutrient restriction during late gestation (Clanton and Zimmerman, 1970; Corah et al., 1975). Also, calf ADG to weaning was not affected by cow BCS $(P=0.92)$ but tended to be greater for calves born to cows that received supplement during the last third of gestation $(P=0.09)$. Because of the greater number of live calves at weaning for the HBCS compared with LBCS cows, the weight weaned per cow was $26 \mathrm{~kg}$ greater $(P=0.004)$ for HBCS, thereby yielding more marketable product. Supplementation had no affect $(P=$ 0.98) on weight weaned.

Initial and final $\mathrm{BW}$ of calves entering the growing lot and, consequently, initial BW of calves entering the feedlot were greater $(P=0.02)$ for calves from HBCS cows compared with calves from LBCS cows (Table 3 ). Also, calf initial BW entering the growing lot tended $(P=0.10)$ to be heavier for supplemented cows compared with nonsupplemented cows. However, no BCS or supplementation treatment effects were observed on calf ADG in the growing lot or feedlot $(P \geq 0.24)$ or on car- cass characteristics $(P \geq 0.16)$. Consequently, our gestational treatments did not affect calf development in a manner that altered growing lot or feedlot performance, including carcass traits, which agrees with data reported by Stalker et al. (2006) in which late gestational supplementation of cows consuming dormant winter range did not alter feedlot performance or carcass traits of the subsequent offspring. This is in contrast to other research in which the HCW (Stalker et al., 2007) and yield grade and marbling score (Larson et al., 2009) of steer progeny from dams that received supplement during the last third of gestation were improved compared to progeny from nonsupplemented dams. An explanation for the inconsistent results is not readily apparent; however, it is possible that differences in prior nutritional status of the cows, winter grazing system, and/or weaning strategies may be responsible for the differences noted. Stalker et al. (2007) weaned cows in mid-August or early November and half of each group was provided a CP supplement from December to March while Larson et al. (2009) evaluated the effect of CP supplementation on 2 winter grazing systems (dormant winter range or corn residue) during late gestation. In our work and Stalker et al. (2006), all cows consumed a common basal diet and all calves were weaned at a common date, within study, thereby minimizing potential confounding of supplementation results by grazing system and weaning strategy. For example, Larson et al. (2009) reported grazing system $\times \mathrm{CP}$ supplementation interactions for calf weaning weight and HCW while Stalker et al. (2007) reported weaning date $\times \mathrm{CP}$ supplementation interactions for finishing $\mathrm{ADG}$ and $\mathrm{HCW}$ of progeny.

Prior research has shown that nutrient restriction during early to mid-gestation negatively affects fetal growth (Wu et al., 2004), including myogenesis and adipogensis (Du et al., 2010, 2011), decreases tenderness and adipose tissue deposition (Underwood et al., 2010), decreases the responsiveness of the hypothalamic-pituitary-adrenal axis in female progeny (Long et al., 2010a), organ development and function (Long et al., 2009), and gene expression (Long et al., 2010b). Nevertheless, even though differences in organ cellular composition and function were noted, Long et al. (2009, 2010b) showed that when beef cows are provided nutrients at a level that meets nutritional requirements during late gestation, it can ameliorate many of the negative consequences (growth and carcass characteristics) of intrauterine growth restriction resulting from early- to midgestational nutrient restriction. Also, other research with late-gestational supplementation of cows has resulted in positive effects on age at puberty and pregnancy rate of female offspring (Martin et al., 2007; Funston et al., 2010). Even though the current study was not designed to specifically ascertain the consequences of early- or 
mid-gestational nutrient restriction on the performance of progeny, our data adds novel information regarding the relationship of BCS, within the range of 4 to 6 , and supplementation of beef cows during late gestation on preweaning and postweaning performance of calves. In addition, our research further substantiates historical data that stresses the importance of maintaining cows in acceptable BCS entering the last third of gestation. Further research is warranted to help elucidate the mechanisms (environmental, nutritional, genetics, gestational period, etc.), and subsequent interactions, by which dam nutrition effects progeny performance.

\section{LITERATURE CITED}

AOAC. 1996. Official Methods of Analysis. 16th ed. Assoc. of Off. Anal. Chem., Arlington, VA.

Barker, D. J. 2004. Developmental origins of well-being. Philos. Trans. R. Soc. Lond. 359:1359-1366.

Bellows, R. A., and R. E. Short. 1978. Effects of precalving feed level on birth weight, calving difficulty and subsequent fertility. J. Anim. Sci. 46:1522-1528.

Bellows, R. A., R. E. Short, D. C. Anderson, B. W. Knapp, and O. F. Pahnish. 1971. Cause and effect relationships associated with calving difficulty and calf birth weight. J. Anim. Sci. 33:407-415.

Bohnert, D. W., C. S. Schauer, and T. DelCurto. 2002. Influence of rumen protein degradability and supplementation frequency on performance and nitrogen use in ruminants consuming lowquality forage: Cow performance and efficiency of nitrogen use in wethers. J. Anim. Sci. 80:1629-1637.

Clanton, D. C., and D. R. Zimmerman. 1970. Symposium on pasture methods for maximum production in beef cattle: Protein and energy requirements for female beef cattle. J. Anim. Sci. 30:122-132.

Corah, L. R., T. G. Dunn, and C. C. Kaltenbach. 1975. Influence of prepartum nutrition on the reproductive performance of beef females and the performance of their progeny. J. Anim. Sci. 41:819-824.

Currier, T. A., D. W. Bohnert, S. J. Falck, and S. J. Bartle. 2004. Daily and alternate day supplementation of urea or biuret to ruminants consuming low-quality forage: I. Effects on cow performance and the efficiency of nitrogen use in wethers. J. Anim. Sci. 82:1508-1517.

DeRouen, S. M., D. E. Franke, D. G. Morrison, W. E. Wyatt, D. F. Coombs, T. W. White, P. E. Humes, and B. B. Greene. 1994 Prepartum body condition and weight influences on reproductive performance of first-calf beef cows. J. Anim. Sci. 72:1119-1125.

Du, M., J. Tong, J. Zhao, K. R. Underwood, M. Zhu, S. P. Ford, and P. W. Nathanielsz. 2010. Fetal programming of skeletal muscle development in ruminant animals. J. Anim. Sci. 88:E51-E60.

Du, M., J. X. Zhao, X. Yan, Y. Huang, L. V. Nicodemus, W. Yue, R. J. McCormick, and M. J. Zhu. 2011. Fetal muscle development, mesenchymal multipotent cell differentiation, and associated signaling pathways. J. Anim. Sci. 89:583-590.

Funston, R. N., J. L. Martin, D. C. Adams, and D. M. Larson. 2010. Winter grazing and supplementation of beef cows during late gestation influence heifer progeny. J. Anim. Sci. 88:4094-4101.

Herd, D. B., and L. R. Sprott. 1996. Body condition, nutrition and reproduction of beef cows. Texas Agric. Ext. Serv. Bull. 1526, College Station, TX.

Larson, D. M., J. L. Martin, D. C. Adams, and R. N. Funston. 2009. Winter grazing system and supplementation during late gestation influence performance of beef cows and steer progeny. J. Anim. Sci. 87:1147-1155.
Long, N. M., M. J. Nijland, P. W. Nathanielsz, and S. P. Ford. 2010a. The effect of early to mid-gestational nutrient restriction on female offspring fertility and hypothalamic-pituitary-adrenal axis response to stress. J. Anim. Sci. 88:2029-2037.

Long, N. M., M. J. Prado-Cooper, C. R. Krehbiel, U. DeSilva, and R. P. Wettemann. 2010b. Effects of nutrient restriction of bovine dams during early gestation on postnatal growth, carcass and organ characteristics, and gene expression in adipose tissue and muscle. J. Anim. Sci. 88:3251-3261.

Long, N. M., K. A. Vonnahme, B. W. Hess, P. W. Nathanielsz, and S. P. Ford. 2009. Effects of early gestational undernutrition on fetal growth, organ development, and placentomal composition in the bovine. J. Anim. Sci. 87:1950-1959.

Martin, J. L., K. A. Vonnahme, D. C. Adams, G. P. Lardy, and R. N. Funston. 2007. Effects of dam nutrition on growth and reproductive performance of heifer calves. J. Anim. Sci. 85:841-847.

NRC. 2000. Nutrient Requirements of Beef Cattle. 7th ed. Natl. Acad. Press, Washington, DC.

Randel, R. D. 1990. Nutrition and postpartum rebreeding in cattle. J. Anim. Sci. 68:853-862.

Reynolds, L. P., P. P. Borowicz, J. S. Caton, K. A. Vonnahme, J. S. Luther, C. J. Hammer, K. R. Maddock Carlin, A. T. Grazul-Bilska, and D. A. Redmer. 2010. Developmental programming: The concept, large animal models, and the key role of uteroplacental vascular development. J. Anim. Sci. 88(E-Suppl.):E61-E72.

Richards, M. W., J. C. Spitzer, and M. B. Warner. 1986. Effect of varying levels of postpartum nutrition and body condition at calving on subsequent reproductive performance in beef cattle. J. Anim. Sci. 62:300-306.

Sanson, D. W., D. C. Clanton, and I. G. Rush. 1990. Intake and digestion of low-quality meadow hay by steers and performance of cows on native range when fed protein supplements containing various levels of corn. J. Anim. Sci. 68:595-603.

Spitzer, J. C., D. G. Morrison, R. P. Wettemann, and L. C. Faulkner. 1995. Reproductive responses and calf birth and weaning weights as affected by body condition at parturition and postpartum weight gain in primiparous beef cows. J. Anim. Sci. 73:1251-1257.

Stalker, L. A., D. C. Adams, T. J. Klopfenstein, D. M. Fuez, and R. N. Funston. 2006. Effects of pre- and postpartum nutrition on reproduction in spring calving cows and calf feedlot performance. J. Anim. Sci. 84:2582-2589.

Stalker, L. A., L. A. Ciminski, D. C. Adams, T. J. Klopfenstein, and R. T. Clark. 2007. Effects of weaning date and prepartum protein supplementation on cow performance and calf growth. Rangeland Ecol. Manage. 60:578-587.

Turner, H. A., and T. DelCurto. 1991. Nutritional and managerial considerations for range beef cattle production. In: J. Maas, editor, Veterinary Clinics of North America: Food Animal Practice. 7th vol. W. B. Saunders, Co., Philadelphia, PA. p. 103.

Tyler, J. W., D. D. Hancock, S. M. Parish, D. E. Rea, T. E. Besser, S. G. Sanders, and L. K. Wilson. 1996. Evaluation of 3 assays for failure of passive transfer in calves. J. Vet. Intern. Med. 10:304-307.

Underwood, K. R., J. F. Tong, P. L. Price, A. J. Roberts, E. E. Grings, B. W. Hess, W. J. Means, and M. Du. 2010. Nutrition during mid to late gestation affects growth, adipose tissue deposition, and tenderness in cross-bred beef steers. Meat Sci. 86:588-593.

Winterholler, S. J., C. P. McMurphy, G. L. Mourer, C. R. Krehbiel, G. W. Horn, and D. L. Lalman. 2012. Supplementation of dried distillers grains with solubles to beef cows consuming low-quality forage during late gestation and early lactation. J. Anim. Sci. 90:2014-2025.

Wu, G., F. W. Bazer, T. A. Cudd, C. J. Meininger, and T. E. Spencer. 2004. Maternal nutrition and fetal development. J. Nutr. 134:2169-2172.

Wu, G., F. W. Bazer, J. M. Wallace, and T. E. Spencer. 2006. Boardinvited review: Intrauterine growth retardation: Implications for the animal sciences. J. Anim. Sci. 84:2316-2337. 